$1-1-1914$

\title{
Some Factors Affecting the Weight, Composition and Hatchability of Hen Eggs
}

Horace Atwood

Follow this and additional works at: https://researchrepository.wvu.edu/ wv_agricultural_and_forestry_experiment_station_bulletins

\section{Digital Commons Citation}

Atwood, Horace, "Some Factors Affecting the Weight, Composition and Hatchability of Hen Eggs" (1914). West Virginia Agricultural and Forestry Experiment Station Bulletins. 145.

https://researchrepository.wvu.edu/wv_agricultural_and_forestry_experiment_station_bulletins/145 
West Virginia University Libraries

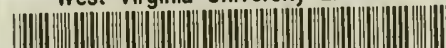

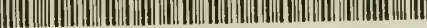

308021008961173 



\section{Jallest Virginia afmínersity Aqrícultural Experiment Station}

MORGANTOWN, W. VA.

POULTRY DEPARTMENT

\section{Some Factors Affecting the Weight, Composition and Hatchability of Hen Eggs}

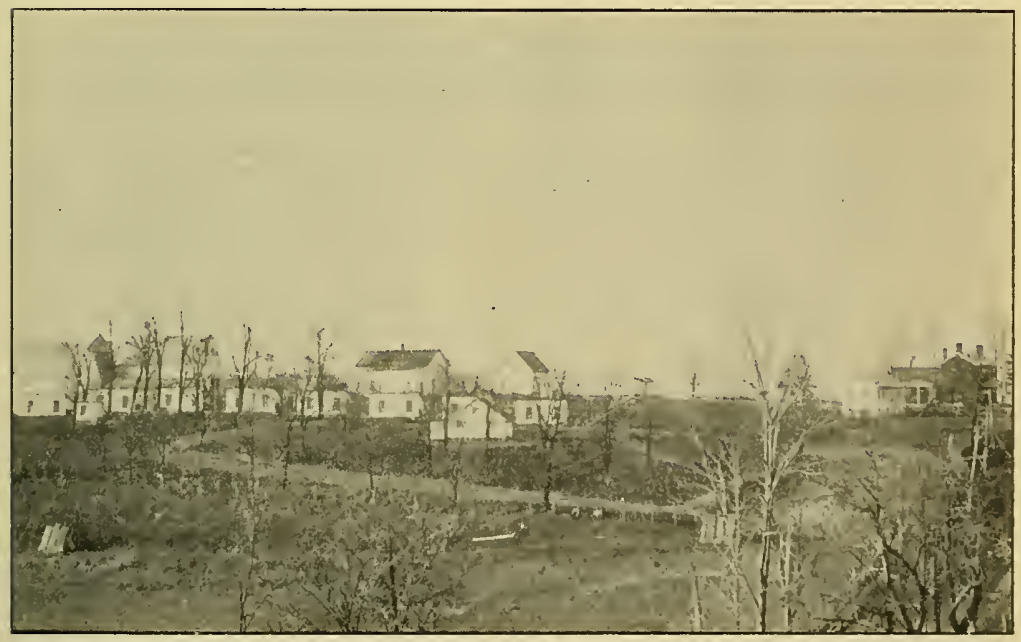

A View at the Agricultural Experiment Station Farm Showing Poultry Buildings and Yards.

BY

HORACE ATWOOD

The Bulletins and Reports of this Station will be mailed free to any citizen of West Virginia upon written application. Address Director of Agricultural Experiment Station, Morgantown, West Virginia. 


\section{THE STATE OF WEST VIRGINIA}

\section{Educational Institutions}

\section{THE STATE BOARD OF CONTROL}

JAMES S. LAKIN, President...................... W. M. O. DAWSON, Treasurer................. Charleston, W. Va.

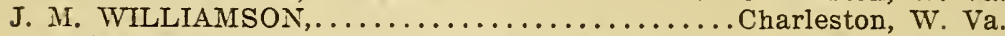

The State Board of Control has the direction of the financial and business affairs of the state educational institutions.

\section{THE STATE BOARD OF REGENTS}

M. P. SHAWKEY, State Superintendent of Schools,

President ....................... Vharleston, W. Va.

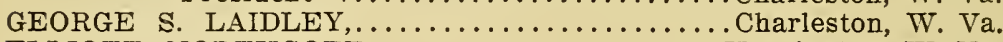

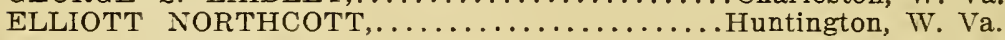
EARL W. OGELBAY,....................... Wheeling, W. Va. J. B. FINLEY, ....................... Parkersburg, W. Va.

The State Board of Regents has charge of all matters of a purely scholastic nature concerning the state educational institutions.

\section{The West Virginia University}

THOMAS EDTVARD HODGES, LL.D.,.................President

\section{Agricultural Experiment Station Staff}

E. Dwight Sanderson, B.S. Agr.,.................. Director Bert H. Hite, M.S.,................... Vice-Director and Chemist W. E. Rumsey, B.S. Agr.,................... State Entomologist

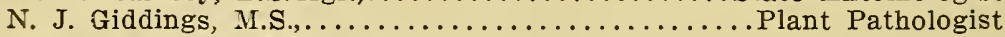
Horace Atwood, M.S. Agr.,........................ Poultryman

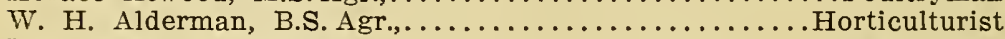

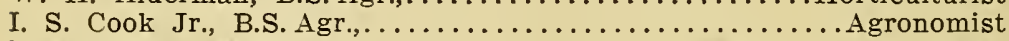

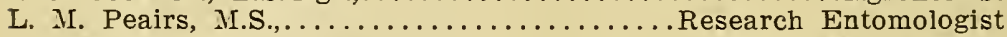
*O. M. Johnson, B.S. Agr.,.................... Farm Management Paul B. Bennetch, B.S. Agr.,.................... Dairy Husbandry

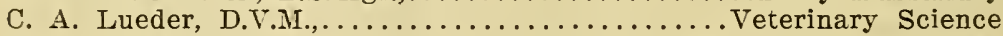

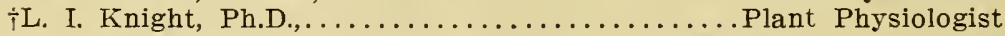

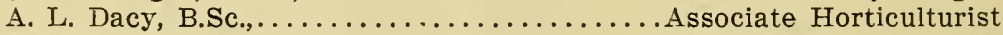
Frank B. Kunst, A.B.,....................sssistant Chemist Charles E. Weakley Jr.,..................... Assistant Chemist

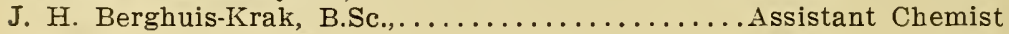

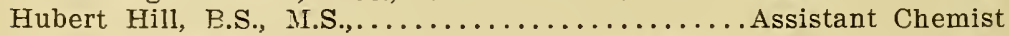

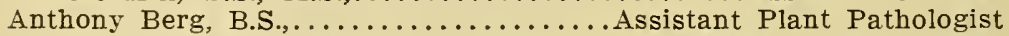
E. C. Auchter, B.S. Agr.,................... Assistant Horticulturist

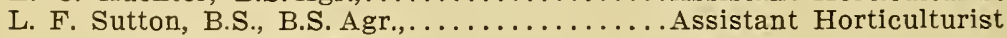

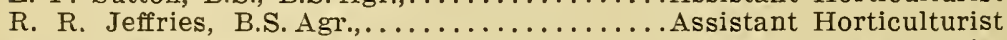

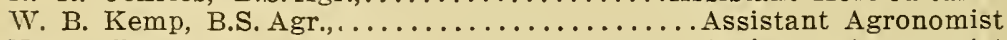

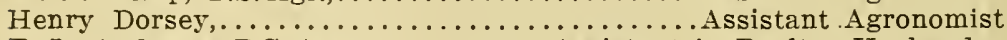
E. L. Andrews, B.S. Agr.,............ Assistant in Poultry Husbandry ${ }^{*}$ C. H. Scherffius,...$\ldots \ldots \ldots \ldots \ldots$. In Charge of Tobacco Experiments O. M. Kile, B.S. Agr.,........................................ W. J. White, $\ldots \ldots \ldots \ldots \ldots \ldots \ldots \ldots \ldots \ldots \ldots \ldots \ldots \ldots \ldots$. Bookkeeper

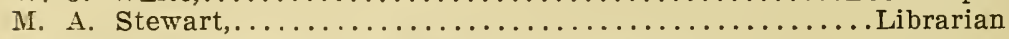




\title{
Some Factors Affecting the Weight, Compo- sition and Hatchability of Hen Eggs
}

\author{
BY HORACE ATWOOD
}

The highest success in keeping poultry cannot be attained unless the little chickens that are reared each year develop into thrifty vigorous individuals. Without this early thrift and vigor the mature fowls never become efficient producers either of eggs or of flesh. They will neither fatten well nor lay well. and instead of being profitable they will be a financial burden, and the enterprise will be unsuccessful. Consequently it is of first importance to know how to produce chickens that are constitutionally strong.

In this bulletin the few experiments that have been performed are reported largely for the purpose of calling attention to the importance of the subject and as a record of progress. Only one or two phases of the subject have been touched upon, and these not exhaustively.

\section{Large Eggs versus Small Eggs for Hatching.}

In bulletin No. 124 of this Station are recorded experiments showing that chickens hatched from heavy eggs are heavier and more thrifty that chicks hatched from eggs lighter in weight. This result, too, has been confirmed recently by investigations conducted by the New York State College of Agriculture at Cornell University, so the general proposition that one should use large heavy eggs for incubating purposes may be accepted as an established fact. It is therefore a matter of importance to know when the heaviest eggs are laid and how fowls should be fed and handled in order that they may lay large heavy eggs best suited for hatching.

\section{Seasonal Variation in the Weight of Eggs.}

That there is a variation in the average weight of eggs according to the season of the year when they are laid was observed by the author in an experiment performed in I899- 
I 900 and reported in bulletin No. 7I of this Station. At that time. however, its significance was not appreciated. The following table from the publication referred to shows the weight of eggs laid by two lots of fowls, one lot supplied liberally with green food, and the other lot with a scanty supply:

Fowls When Receiving Green Food.

\begin{tabular}{|c|c|c|c|}
\hline LOT I & 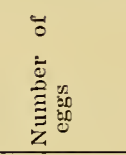 & 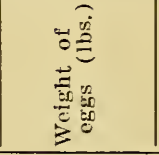 & 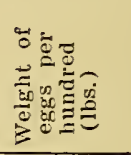 \\
\hline \multirow{13}{*}{ 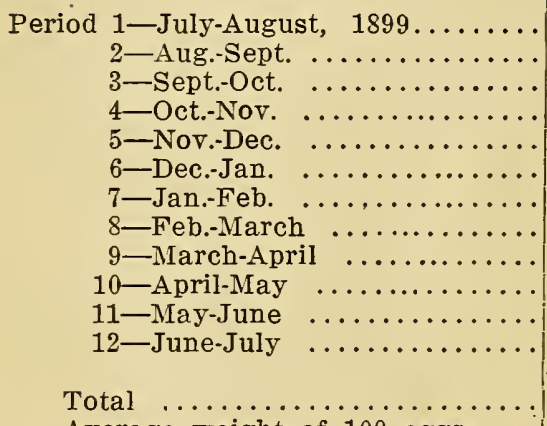 } & 660 & 74.5 & 11.28 \\
\hline & 680 & 76.5 & 11.25 \\
\hline & 945 & 112.5 & 11.90 \\
\hline & 1,020 & 122.0 & 11.96 \\
\hline & 675 & $\$ 3.5$ & 12.37 \\
\hline & 290 & 35.7 & 12.32 \\
\hline & 330 & 42.0 & 12.72 \\
\hline & 930 & 114.0 & 12.26 \\
\hline & 1,595 & 201.5 & 12.63 \\
\hline & 1,600 & 185.7 & 11.61 \\
\hline & 1,542 & 174.4 & 11.31 \\
\hline & 1,185 & 131.2 & 11.07 \\
\hline & 11,452 & $1,353.5$ & \\
\hline Average weight of $100 \mathrm{eg}$ & & $\ldots \ldots \ldots$ & 11.89 \\
\hline
\end{tabular}

Fowls When Not Receiving Green Food.

\begin{tabular}{|c|c|c|c|}
\hline LOT II & 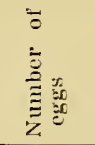 & 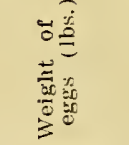 & 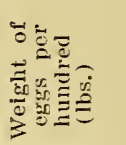 \\
\hline \multicolumn{4}{|l|}{2} \\
\hline Period 1-July-Aug., $1899 \ldots \ldots \ldots \ldots$ & 710 & 79.5 & 11.19 \\
\hline 2-Aug.-Sept. $\quad \ldots \ldots \ldots \ldots \ldots \ldots$ & 865 & 96.0 & 11.09 \\
\hline 3-Sept.-Oct. . . . . . . . . & 610 & 70.0 & 11.47 \\
\hline 4 -Oct.-Nov. $\ldots \ldots \ldots \ldots \ldots \ldots$ & 710 & 81.5 & 11.48 \\
\hline 5-Nov.-Dec. $\quad \ldots \ldots \ldots \ldots \ldots \ldots$ & 385 & 45.5 & 11.81 \\
\hline 6-Dec.-Jan. $\quad \ldots \ldots \ldots \ldots \ldots \ldots$ & 355 & 44.2 & 12.46 \\
\hline 7-Jan.-Feb. .............. & 90 & 12.0 & 13.33 \\
\hline 8-Feb.-March $\ldots \ldots \ldots \ldots \ldots$ & 735 & 96.0 & 13.06 \\
\hline 9-March-April ....... & 975 & 117.0 & 12.00 \\
\hline 10-April-May $\ldots \ldots \ldots \ldots \ldots$ & 994 & 118.8 & 11.24 \\
\hline 11-May-June...$\ldots \ldots \ldots$. & 1,400 & 158.6 & 11.33 \\
\hline 12-June-July $\ldots \ldots \ldots$ & 1,210 & 147.2 & 12.16 \\
\hline Total $\ldots \ldots \ldots \ldots \ldots \ldots \ldots$ & 9,039 & $1,066.3$ & \\
\hline Average weight of 100 eggs & & . & 11.88 \\
\hline
\end{tabular}




\section{LIBERAL FEEDING VERSUS SCANTY FEEDING AS AFFECTING WEIGHT AND HATCHABILITY OF EGGS.}

\section{EXPERIMENTS CONDUCTED IN 1911-1912.}

On August I, I9I I an experiment was begun with six lots of fowls to determine the effect of liberal versus scanty feeding, upon the number and weight of eggs produced and their hatchability. This experiment was continued for two years with the same fowls. The eggs from each lot of fowls were weighed regularly two or three times per week in bulk, and the following tables give the weight of the fowls, the amount of food consumed, the number of eggs laid and their weight (in grams) for each month of the year:

Pens $3,4,7$ and 8 contained pullets, and pens 5 and 6 one year old hens. All pens were fed a moistened mash containing corn meal, wheat bran, wheat middlings and beef scrap. In the afternoon they were fed whole grain scattered in the straw litter that covered the floors of the houses. Pens 3,4 and 5 were fed liberally for egg production, while pens 6,7 and 8 were fed the same materials, but less liberally, so that few eggs were produced during the winter months. Due to the liberal feeding of pens 3 and 4 during the fall months, several of the pullets moulted at the approach of cold weather, thus materially reducing their winter egg production. After April Ioth, pens 6 and 7 were also fed in a normal manner, and pen 8 after May 28 th.

The following table shows the weights of each lot of 20 females and one male at the beginning of the test and at different times throughout the year:

Weight of Fowls in Feeding Experiments.

(Weight in pounds.)

\begin{tabular}{|c|c|c|c|c|c|c|}
\hline & Pen 3 & Pen 4 & Pen 5 & Pen 6 & Pen 7 & Pen 8 \\
\hline $\begin{array}{l}\text { Aug. } 1,1911 \ldots \ldots \ldots \ldots \ldots \ldots \\
\text { Aug. } 24,1911 \ldots \ldots \ldots \ldots \ldots \\
\text { Sept. } 1,1911 \ldots \ldots \ldots \ldots \ldots \\
\text { Oct. } 1,1911 \ldots \ldots \ldots \ldots \ldots \\
\text { Nov. } 1,1911 \ldots \ldots \ldots \ldots \ldots \ldots \\
\text { Dec. } 1,1911 \ldots \ldots \ldots \ldots \ldots \ldots \\
\text { Jan. } 1,1912 \ldots \ldots \ldots \ldots \ldots \ldots \\
\text { March } 1,1912 \ldots \ldots \ldots \ldots \ldots \\
\text { April } 11,1912 \ldots \ldots \ldots \ldots \ldots \\
\text { Aug. 1, } 1912 \ldots \ldots \ldots \ldots \ldots \ldots\end{array}$ & $\begin{array}{l}50.5 \\
56 . \\
60 . \\
65 . \\
75.5 \\
77.5 \\
78.5 \\
\$ 3.5 \\
\$ 9.5 \\
79.75\end{array}$ & $\begin{array}{l}49 . \\
56.5 \\
59 . \\
67 . \\
74.5 \\
76.5 \\
77.5 \\
77 . \\
87.5 \\
80 .\end{array}$ & $\begin{array}{l}79 . \\
74 . \\
70 . \\
74 . \\
76.5 \\
80.5 \\
90.5 \\
93.5 \\
80 .\end{array}$ & $\begin{array}{l}77 . \\
67 . \\
63.5 \\
61.5 \\
61.5 \\
66 . \\
69.25 \\
66.5 \\
68.5\end{array}$ & $\begin{array}{l}49 . \\
54 . \\
57 . \\
58 . \\
63 . \\
66.5 \\
66 . \\
66.5 \\
68.5 \\
70.75\end{array}$ & $\begin{array}{l}49.5 \\
55.5 \\
59 . \\
59 . \\
63.5 \\
69 . \\
67.5 \\
66.5 \\
63.5 \\
65 .\end{array}$ \\
\hline
\end{tabular}


The table shows that of the fowls fed liberally there was a fairly uniform increase in weight from the beginning of the experiment until April IIth, then there was a decrease, showing that fowls are heaviest during the period of maximum egg production. The mature fowls fed scantily, pen 6 , never weighed as much as at the beginning of the experiment while the two pens of pullets fed scantily gradually increased in weight.

The following table shows the pounds of feed consumed during the year by each lot of $2 \mathrm{I}$ fowls:

Feed Consumed by Each Pen of Fowls.

(Weight in pounds.)

\begin{tabular}{|c|c|c|c|c|c|c|}
\hline & Pen 3 & $\mid$ Pen $4 \mid$ & Pen 5| & $|\operatorname{Pen} 6|$ & Pen 7 & Pen 8 \\
\hline Corn & 304.5 & 309.5 & 297.5 & 241.5 & 240.5 & 188.5 \\
\hline Wheat. & 215. & 215. & 205. & 185. & 185. & 115. \\
\hline Oats ........ & 382. & 387. & $375:$ & 299. & 298. & 242. \\
\hline Corn meal .... & 176.6 & 176.6 & 181.6 & 136.6 & 139.6 & 130.6 \\
\hline Wheat bran ..... & 176.6 & 176.6 & 181.6 & 136.6 & 139.6 & 130.6 \\
\hline Wheat middlings ... & 126. & 126. & 125. & 101. & 108. & 95. \\
\hline Cottonseed meal .. & 22 . & 22. & 23. & 16. & 19. & 15. \\
\hline Ground oats $\ldots \ldots \ldots \ldots$ & 62.6 & 62.6 & 56.6 & 51.6 & 51.6 & 51.6 \\
\hline Beef scrap $\ldots \ldots \ldots \ldots \ldots$. & 61. & 61. & 61. & 47. & 47. & 45. \\
\hline Total $\ldots \ldots \ldots \ldots$ & $1,526.3$ & $1,536.3$ & $1,506.3$ & $1,214.3$ & $1,228.3$ & $1,013.3$ \\
\hline
\end{tabular}

The fowls fed liberally consumed during the rear an average of 72.5 pounds of grain and beef scrap each, while those fed scantily each consumed 54.8 pounds of the same feeding stuff.

The following tables show the number and total weight, in grams, of the egg's laid each month by each pen of fowls; the average weight of the eggs each month, and the average weight of all the eggs laid by each pen for the year. 
Number and Weight of Eggs Laid by Each Pen.

(Weight in grams.)

\begin{tabular}{|c|c|c|c|c|c|c|c|c|c|}
\hline \multirow[b]{2}{*}{ Month } & \multicolumn{3}{|c|}{ PEN 3} & \multicolumn{3}{|c|}{ PEN 4} & \multicolumn{3}{|c|}{ P E N 5} \\
\hline & 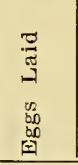 & 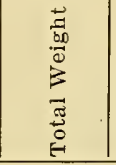 & 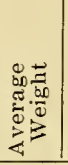 & 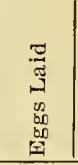 & $\begin{array}{l}\frac{\vec{\pi}}{0} \\
\frac{.00}{0} \\
3 \\
\bar{\pi} \\
0 \\
0\end{array}$ & 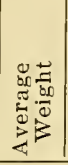 & 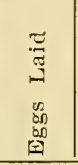 & 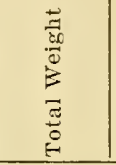 & 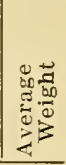 \\
\hline Aug., 1911..... & & & & & & & 252 & 14,365 & 57.0 \\
\hline Sept...$\ldots \ldots \ldots$ & 16 & 646 & 40.4 & 57 & 2,380 & 41.7 & 114 & 6,271 & 55.0 \\
\hline Oct. $\ldots \ldots$ & 32 & 1,533 & 47.9 & 46 & 2,047 & 44.5 & 47 & 2,649 & 56.4 \\
\hline Nov, ... & 151 & 7,727 & 51.2 & 60 & 3,164 & 52.7 & 6 & 351 & 58.5 \\
\hline Dec. .... & 188 & 10,293 & 54.7 & 168 & 9,143 & 54.4 & 30 & 1,916 & 63.8 \\
\hline Jan., $1912 \ldots .$. & 53 & 2,990 & 56.4 & 151 & 8,666 & 57.4 & 20 & 1,236 & 61.8 \\
\hline Feb. ........ & 194 & 11,481 & 59.2 & 232 & 13,743 & 59.2 & 166 & 10,119 & 60.9 \\
\hline Mar. ... & 452 & 26,976 & 59.6 & 444 & 26,256 & 59.1 & 386 & 24,006 & 62.2 \\
\hline Apr. & 459 & 26,849 & 58.5 & 407 & 23,673 & 58.1 & 408 & 24,805 & 60.8 \\
\hline May & 463 & 26,392 & 57.0 & 438 & 24,820 & 56.6 & 415 & 24,502 & 59.0 \\
\hline June .. & 477 & 26,809 & 56.2 & 477 & 27,062 & 56.7 & 426 & 24,923 & 58.5 \\
\hline July $\ldots$ & 309 & 17,214 & 55.7 & 275 & 15,072 & 54.8 & 243 & 13,668 & 56.2 \\
\hline $\begin{array}{l}\text { Total .... } \\
\text { Average } . .\end{array}$ & 2,794 & 158,910 & 56.8 & 2,755 & 156,026 & 56.6 & 2,513 & 148,811 & 59.2 \\
\hline
\end{tabular}

The total number of eggs produced by pens 3,4 and 5 was 8062 . The total weight of these eggs was 463.747 grams. The average weight of the eggs for the year was 57.5 grams.

\begin{tabular}{|c|c|c|c|c|c|c|c|c|c|}
\hline \multirow[b]{2}{*}{ MONTH } & \multicolumn{3}{|c|}{ P E N 6} & \multicolumn{3}{|c|}{ P E N 7} & \multicolumn{3}{|c|}{ PEN S } \\
\hline & $\begin{array}{l}3 \\
3 \\
3 \\
0 \\
0 \\
00 \\
00 \\
0 \\
\end{array}$ & $\begin{array}{l}\overrightarrow{0} \\
\frac{\overrightarrow{0}}{0} \\
0 \\
\overrightarrow{0} \\
\overrightarrow{0} \\
0\end{array}$ & 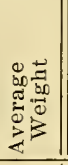 & 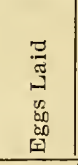 & $\begin{array}{l}\vec{J} \\
.00 \\
0 \\
0 \\
\overrightarrow{0} \\
\overrightarrow{0} \\
0 \\
\stackrel{0}{0}\end{array}$ & 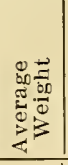 & 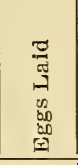 & 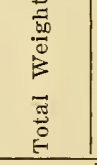 & 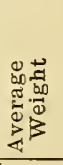 \\
\hline Aug., $1911 \ldots$. & 223 & 12,609 & 56.5 & & & & & & \\
\hline Sept. ....... & 50 & 2,746 & 54.9 & & & & 17 & 664 & 39.1 \\
\hline Oct. $\ldots \ldots \ldots$ & 5 & 309 & 61.8 & & & & 22 & 1,102 & 50.1 \\
\hline Nov. ........ & & & & & & & 28 & 1,484 & 53.0 \\
\hline Dec, $\ldots \ldots \ldots$ & & & & 9 & 431 & 47.9 & 27 & 1,426 & 52.8 \\
\hline Jan., $1912 . . .$. & 1 & 58 & 58.0 & 5 & 243 & 48.6 & 4 & 232 & 58.0 \\
\hline Feb. ... & 98 & 6,062 & 61.5 & 139 & 7,967 & 57.3 & 150 & 9,036 & 60.2 \\
\hline March & 81 & 4,874 & 60.1 & 28 & 1,562 & 55.7 & 75 & 4,278 & 57.0 \\
\hline April & 305 & 17,946 & 58.8 & 305 & 17,526 & 57.4 & 231 & 13,071 & 56.6 \\
\hline May & 449 & 25,945 & 57.8 & 484 & 28,219 & 58.3 & 310 & 17,464 & 58.0 \\
\hline June & 462 & 26,150 & 56.6 & 484 & 28,103 & 58.0 & 398 & 22,842 & 57.4 \\
\hline July & 273 & 15,109 & 55.3 & 301 & 16,797 & 55.8 & 189 & 10,584 & 56.0 \\
\hline Total ... & 1,947 & 111,808 & & 1,755 & $100,84 \mathrm{~S}$ & & 1,422 & 82,183 & \\
\hline Average & & & 57.4 & & & 57.4 & & & 56.9 \\
\hline
\end{tabular}


The total number of eggs produced by pens 6,7 and 8 was 5,I 44. The total weight of these eggs was 294,839 grams. The average weight of the eggs for the year was 57.3 grams.

Number of Eggs Laid. The three pens of fowls fed liberally, laid 8062 eggs and those fed scantily laid 5144. This shows the importance of liberal feeding in the economical production of eggs. It takes a certain amount of feed to maintain the warmth of the fowls, to repair and build up their systems, and to supply energy for their normal activity. These requirements must be met before any of the nutritive materials can be used for the formation of eggs.

The two pens of pullets fed liberally averaged I 38.7 eggs each, while the pen of yearling hens fed liberally laid only I25.6 eggs each, showing that the greatest egg production is to be expected during the pullet year.

Weight of Eggs. The eggs laid by pen 3 in September averaged 40.4 grams each, and there was a gradual increase in weight until during March, when the eggs averaged 59.6 grams each. Then there was a slight but gradual decrease until the close of the first year when the eggs averaged for the last month only 55.7 grams. This variation is also plainly evident in pens 4 and 5 and to a certain extent in the case of the pens fed scantily. In the case of pens 6.7 and 8 , variations in the liberality of their food supply introduced another factor influencing the weight of the eggs.

The records for the years I899-I900 and I9II-I9I2 both show that the heaviest eggs are laid during February, March and April. The reason for this may not be clearly evident. but it certainly throws additional light on the subject and explains why early hatched chickens are almost universally considered more hardy and rigorous than those hatched later in the season.

Scanty Feeding Reduces Size of Egg. Coming now to the influence of scanty feeding on the size of the eggs, the tables show that the average weight of the eggs laid during the year, by the fowls fed liberally was 57.5 grams, and the average for the other fowls was 57.3 grams. This is only a slight decrease. hut it must be remembered that pens 6 and 7 were fed liberally after April Ioth, and pen 8 after May 28th.

During the month of March, the eggs from pens I. 2 and 3 averaged 60.3 grams each, while the eggs from the other pens averaged 57.6 grams, or a decrease of about $4^{1 / 2}$ per cent, so we may safely conclude that scanty feeding reduces slightly the size of the eggs. 
Hatchability of Eggs and Vigor of Chicks.

The eggs in this experiment were incubated in Cyphers 390-egg size incubators. Whenever two or more incubators were used the eggs from each lot of fowls were uniformily distributed among the machines, so that any variation during the hatching period would affect each lot of eggs alike. The incubators were operated in the usual manner, and the variations in the temperature of the egg chambers were very slight.

The following table gives the essential details of the first hatch :

$$
\text { HАTCH 1-March 22, } 1912 .
$$

\begin{tabular}{|c|c|c|}
\hline & $\begin{array}{c}\text { Fowls fed } \\
\text { heavily }\end{array}$ & $\begin{array}{l}\text { Fowls fed } \\
\text { scantily }\end{array}$ \\
\hline Number of eggs incubated......... & 845 & 94 \\
\hline 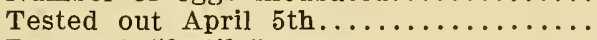 & 288 & 54 \\
\hline Per cent "fertile" eggs............ & 65.9 & 42.6 \\
\hline 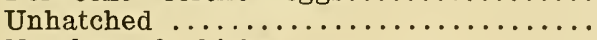 & 101 & 9 \\
\hline Number of chicks........... & 456 & 31 \\
\hline Per cent hatch of "fertile" eggs. & 81.9 & 77.5 \\
\hline Per cent hatch of all eggs incubated.... & 53.9 & 32.9 \\
\hline
\end{tabular}

The eggs from the fowls fed scantily were less strongly fertilized than the others and a slightly less number of the fertile eggs hatched.

Both lots of chicks, together with 373 others of the same age were placed in an Arenburg brooder and brooded in one flock. The experimental chicks were not marked, so there is no record of the mortality of each lot. A record was kept, however, of the deaths occurring among the entire 860 chicks. There were 8 deaths during the first three days after the chickens were placed in the brooder. These were undoubtedly weak or defective chickens. Of the 852 remaining, there was only one death until they were removed to colony houses at twelve weeks of age. This shows plainly that all the chickens in this flock from whatever source were remarkably strong and healthy. 


\begin{tabular}{|c|c|c|}
\hline & $\begin{array}{c}\text { Fowls fed } \\
\text { heavily }\end{array}$ & $\begin{array}{l}\text { Fowls fed } \\
\text { scantily }\end{array}$ \\
\hline 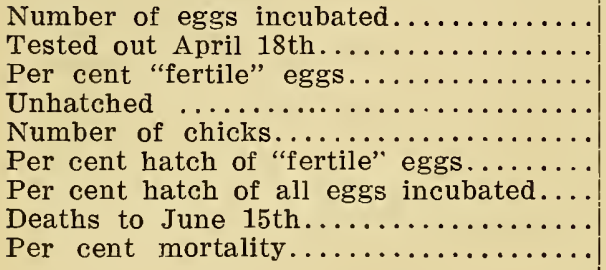 & $\begin{array}{r}200 \\
12 \\
94 \\
23 \\
165 \\
87.7 \\
82.5 \\
12 \\
7.3\end{array}$ & $\begin{array}{r}93 \\
13 \\
86 \\
6 \\
74 \\
92.5 \\
79.5 \\
0 \\
0\end{array}$ \\
\hline
\end{tabular}

In this hatch, also the eggs from the fowls fed scantily were not so fertile as those from the other lot of fowls. The fertile eggs however, hatched somewhat better, the net result being that a slightly greater percentage hatched from the eggs laid by the fowls fed liberally.

The mortality was greater in the chicks hatched from eggs laid by the fowls fed liberally. The chicks were brooded in a Cornell gasoline brooder.

HATCH :-April 20, $191 \%$.

\begin{tabular}{|c|c|c|}
\hline & $\begin{array}{c}\text { Fowls fed } \\
\text { heavily }\end{array}$ & $\begin{array}{l}\text { Fowls fed } \\
\text { scantily }\end{array}$ \\
\hline Number of eggs incubated........... & 377 & 239 \\
\hline 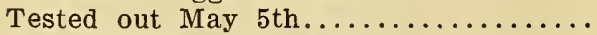 & 28 & 32 \\
\hline Per cent "fertile" eggs.......... & 92.6 & 86.6 \\
\hline Unhatched $\ldots \ldots \ldots \ldots$. & 52 & 22 \\
\hline Number of chicks.......... & 297 & 185 \\
\hline Per cent hatch of "fertile" eggs. & 85.1 & 89.3 \\
\hline Per cent hatch of all eggs incubated. & 78.7 & 77.4 \\
\hline Weight of 100 chicks just hatched (lbs.) & 8.77 & 8.38 \\
\hline Per cent mortality first six weeks... & 3.8 & 1.6 \\
\hline
\end{tabular}

In this hatch the eggs from the fowls fed liberally were somewhat more fertile, but the fertile eggs did not hatch quite so well as the eggs from the other lot, the final result being that there was practically the same percentage of chicks from both lots of eggs. 


\begin{tabular}{|c|c|c|}
\hline & $\begin{array}{c}\text { Fowls fed } \\
\text { heavily }\end{array}$ & $\begin{array}{l}\text { Fowls fed } \\
\text { scantily }\end{array}$ \\
\hline 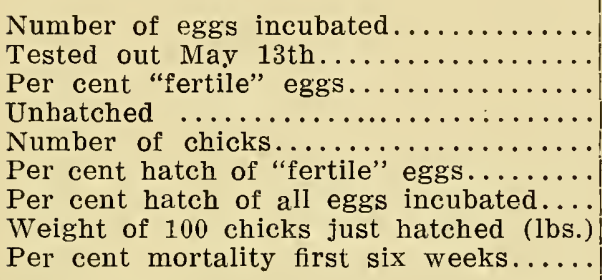 & $\begin{array}{r}189 \\
23 \\
87.8 \\
20 \\
146 \\
87.9 \\
77.8 \\
8.58 \\
4.1\end{array}$ & $\begin{array}{r}185 \\
23 \\
87.6 \\
19 \\
143 \\
88.2 \\
77.3 \\
8.73 \\
0 .\end{array}$ \\
\hline
\end{tabular}

Both lots of eggs hatched practically the same. The mortality however, was slightly greater in the chicks hatched from eggs laid by the heavily fed pen of fowls, although the deaths in this lot were few. The chicks were brooded in one flock in a Cornell gasoline brooder.

НАТСH 5-May 22, 1912.

\begin{tabular}{|c|c|c|}
\hline & $\begin{array}{l}\text { Fowls fed } \\
\text { heavily }\end{array}$ & $\begin{array}{l}\text { Fowls fed } \\
\text { scantily }\end{array}$ \\
\hline 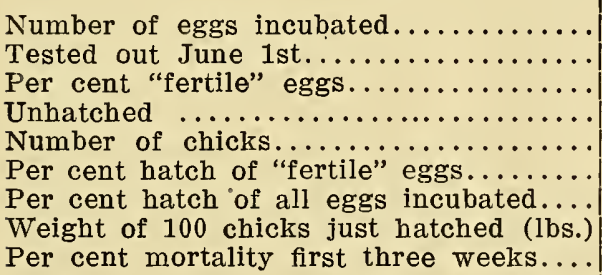 & $\begin{array}{r}393 \\
78 \\
80.2 \\
50 \\
265 \\
84.1 \\
67.4 \\
8.92 \\
\mathbf{1 . 5}\end{array}$ & $\begin{array}{r}390 \\
46 \\
88.2 \\
32 \\
312 \\
90.7 \\
80.0 \\
8.80 \\
2.9\end{array}$ \\
\hline
\end{tabular}

The eggs laid by the fowls that had been fed scantily were more fertile and hatched considerably better than those laid by the other lot of fowls. The chicks were toe-marked and brooded with about 500 others of the same age in an Arenburg brooder. During the first three weeks the mortality was somewhat greater in the case of the chicks hatched from the eggs from the fowls that had been fed scantily. In both cases, however the death loss was low. 


\section{Summary of IgII-IgI2 Incubating and Brooding Experiments.}

The tests indicate that when fowls are fed too scantily the fertility of the eggs will be low, but those which are fertile seem to hatch practically as well as the fertile eggs laid by the fowls fed heavily. Hatch 5 indicates that after fowls have been laying heavily for a considerable length of time their eggs are less fertile and do not hatch so well as eggs laid by fowls which are just reaching or have reached their maximum egg production for the season. There seems to be no great difference in the vigor of the chicks from the two lots of fowls, although what difference there is seems to be in favor of the chicks from the fowls fed scantily, except in the case of the last hatch.

\section{EXPERIMENTS CONDUCTED IN 1912-1913.}

The experiment begun August Ist, I9II with six pens of fowls was continued for the second year with the same fowls and on the same general plan, pens 3,4 and 5 being fed liberally, and pens 6,7 and 8 being fed scantily.

The following table shows the kind and amount of feed consumed by each lot of fowls for the twelve months under consideration :

Feeds Consumed by Fouls From August, 1912, to July, 1913. (Weight in pounds.)

\begin{tabular}{|c|c|c|c|c|c|c|c|}
\hline & Pen 3 & Pen $4 \mid$ & Pen 5 & Pen 6 & Pen 7 & Pen 8 & Total \\
\hline Corn $\ldots \ldots \ldots \ldots \ldots$ & 475.2 & 4.73 .5 & 476.4 & 277.5 & 304.0 & 280.5 & \\
\hline Oats $\ldots \ldots \ldots \ldots \ldots$ & 475.2 & 473.5 & 476.4 & 277.5 & 304.0 & 280.5 & \\
\hline Corn meal .......... & 166.5 & 168.6 & 158.8 & 106.4 & 106.7 & 121.8 & \\
\hline Wheat bran ........ & 103.3 & 103.8 & 96.4 & 61.7 & 69.3 & 73.9 & \\
\hline Wheat middlings ..... & 145.5 & 151.8 & 146.8 & 93.4 & 94.7 & 85.8 & \\
\hline Beef scrap $\ldots \ldots \ldots \ldots$ & 87.3 & 87.8 & 83.4 & 59.7 & 51.8 & 64.4 & \\
\hline Fresh meat and bone.. & 51.0 & 41.6 & 41.6 & 41.6 & 35.2 & 41.6 & \\
\hline Cottonseed meal ..... & 10.9 & 11.0 & 9.0 & 7.0 & 8.0 & 5.0 & \\
\hline Gluten meal ........ & 12.0 & 16.8 & 12.0 & 12.0 & 12.0 & 33.8 & \\
\hline Sprouted oats ....... & 47.7 & 48.7 & 48.7 & 48.7 & 48.7 & 48.7 & \\
\hline Oil meal $\ldots . . . \ldots \ldots$ & 21.8 & 21.6 & 21.1 & 15.6 & 12.4 & 16.0 & \\
\hline Milk $\ldots \ldots \ldots \ldots \ldots \ldots$ & $(290)$ & $(290)$ & $(290)$ & $(290)$ & $(290)$ & $(290)$ & \\
\hline Shredded alfalfa ..... & 21.8 & 21.6 & 20.8 & 15.6 & 12.4 & 16.0 & \\
\hline Total & $1,618.2$ & $1,620.3$ & $1,591.4$ & $1,016.7$ & $1,059.2$ & $1,068.0$ & $7,973.8$ \\
\hline
\end{tabular}

Total pens 3,4 and $5 \ldots \ldots \ldots \ldots \ldots 4,829.9$

Total pens 6,7 and $8 \ldots \ldots \ldots, 143.9$ 
Weight of Fouls in Fach Pen by Months.

19912

1913

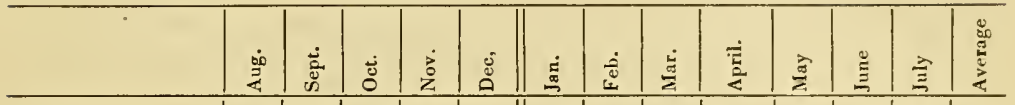

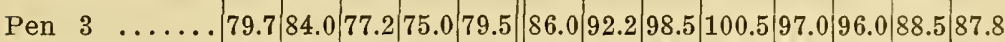

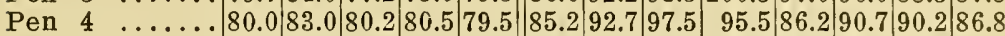

\begin{tabular}{lll|l|l|l|l|l|l|l|l|l|l|l|l|l|l|l|l|} 
Pen 5 & $\ldots \ldots$ & 80.0 & 85.0 & 78.7 & 77.0 & 78.2 & 85.0 & 90.7 & 97.5 & 95.5 & 93.0 & 93.7 & 87.5 & 86.8
\end{tabular}

\begin{tabular}{lll|l|l|l|l|l|l|l|l|l|l|l|l|l|l|l|l|l|} 
Pen 6 & $\ldots \ldots$ & 68.5 & 71.0 & 61.2 & 54.5 & 63.0 & 73.0 & 82.7 & 76.0 & 71.2 & 66.5 & 64.5 & 59.0 & 67.6
\end{tabular}

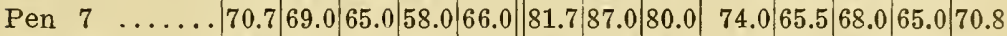

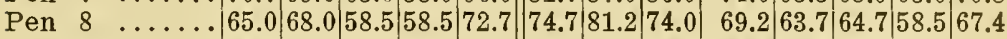

\begin{tabular}{ll|l|l|l|l|l|l|l|l|l|l|l|l|} 
Average $\ldots . . .6$ & 73.9 & 76.6 & 70.1 & 67.2 & 73.1 & 80.9 & 87.7 & 87.2 & 84.3 & 78.6 & 79.6 & 74.8 \\
\hline
\end{tabular}

Average weight of pens 3,4 and $5 \ldots \ldots 87.1 \mathrm{lbs}$.

Average weight of pens 6,7 and $8 \ldots \ldots 68.6 \mathrm{lbs}$.

This table shows that the liberally fed fowls remained heavier throughout the year; also that the fowls were heavier during the months of January, February, March and April than at any other time.

The following table shows the number of eggs laid by each pen of fowls for each month in the year:

Total Number of Eggs Laid, by Months.

\begin{tabular}{|c|c|c|c|c|c|c|c|}
\hline & Pen 3 & Pen 4 & Pen 5 & Pen 6 & Pen 7 & Pen 8 & Tota1 \\
\hline August, $1912 \ldots \ldots \ldots$ & 287 & 245 & 167 & 157 & 152 & 85 & 1,093 \\
\hline September $\ldots \ldots \ldots$. & 203 & 195 & 156 & 64 & 69 & 42 & 729 \\
\hline October $\ldots \ldots \ldots \ldots$ & 67 & 39 & 44 & & 1 & 2 & 153 \\
\hline Norember $\ldots . . . \ldots$ & 1 & & & & 1 & & 2 \\
\hline December $\ldots \ldots \ldots \ldots$ & 8 & 1 & & 3 & & 19 & 31 \\
\hline January, 1913 ....... & 13 & 35 & 32 & 33 & 64 & 46 & 223 \\
\hline February $\ldots \ldots \ldots \ldots$ & 57 & 75 & 55 & 77 & 83 & 110 & 457 \\
\hline March $\ldots \ldots \ldots \ldots$ & 314 & 357 & 339 & 191 & 180 & 209 & 1,590 \\
\hline April $\ldots \ldots \ldots \ldots \ldots$ & 379 & 406 & 379 & 161 & 183 & 175 & 1,683 \\
\hline May $\ldots \ldots \ldots \ldots \ldots \ldots$ & 399 & 359 & 376 & 157 & 113 & 138 & 1,542 \\
\hline June $\ldots \ldots \ldots \ldots$ & 360 & 347 & 344 & 215 & 159 & 234 & 1,659 \\
\hline July $\ldots \ldots \ldots \ldots$ & 336 & 315 & 286 & 153 & 121 & 145 & 1,356 \\
\hline Total ... & 2,424 & 2,374 & 2,178 & 1,211 & 1,126 & 1,205 & 10,518 \\
\hline
\end{tabular}

The above table shows that the heaviest production was during the months of March, April, May and June. Comparing this with the average weights shown in the preceding table it is seen that fowls reach their maximum weight slightly before they reach their maximum production. 
Disregarding the results for December, on account of the small number of eggs laid that month, the table shows that the average weight of the eggs during January, February and March is greater than at any other time of the year. This result is in complete harmony with former findings.

The Following Table Shous the Total Weight, in Grams, of all the Eggs Laid for Each Month in the Year, and the Average Weight of Eggs:

\begin{tabular}{|c|c|c|c|c|c|c|c|c|}
\hline Month & $\begin{array}{l}\because \\
\Xi \\
\Xi\end{array}$ & $\begin{array}{l}\overrightarrow{1} \\
\tilde{\Xi}\end{array}$ & $\begin{array}{l}\stackrel{L}{0} \\
\stackrel{0}{*}\end{array}$ & $\begin{array}{l}0 \\
\equiv \\
\vdots\end{array}$ & $\bar{\Xi}$ & $\begin{array}{l}\infty \\
\Xi \\
0\end{array}$ & : & 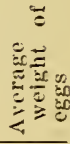 \\
\hline 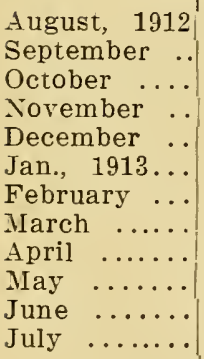 & $\begin{array}{r}16,608 \\
12,072 \\
4,039 \\
61 \\
491 \\
782 \\
3,520 \\
19,064 \\
22,599 \\
23,038 \\
20,606 \\
19,315\end{array}$ & \begin{tabular}{|r|}
14,063 \\
11,457 \\
2,268 \\
\\
58 \\
2,045 \\
4,329 \\
21,785 \\
24,075 \\
20,856 \\
20,071 \\
18,343
\end{tabular} & $\begin{array}{r}1,830 \\
3,148 \\
20,938 \\
23,512 \\
20,614 \\
20,716 \\
16,903\end{array}$ & \begin{tabular}{|r|}
8,736 \\
3,731 \\
\\
206 \\
2,097 \\
4,800 \\
11,252 \\
9,003 \\
8,566 \\
11,767 \\
8,446
\end{tabular} & $\begin{array}{r}8,451 \\
3,877 \\
57 \\
51 \\
\\
3,960 \\
5,180 \\
10,546 \\
10,361 \\
6,208 \\
9,009 \\
6,809\end{array}$ & $\begin{array}{r}4,852 \\
2,381 \\
96 \\
\\
1,148 \\
3,003 \\
6,685 \\
12,348 \\
9,904 \\
7,522 \\
13,089 \\
8,261\end{array}$ & $\begin{array}{r}62,545 \\
42,913 \\
9,174 \\
112 \\
1,903 \\
13,717 \\
27,562 \\
95,933 \\
99,454 \\
86,804 \\
95,258 \\
78,137\end{array}$ & $\begin{array}{l}57.2 \\
58.8 \\
59.9 \\
56.0 \\
61.4 \\
61.5 \\
60.3 \\
60.3 \\
59.1 \\
56.3 \\
57.4 \\
57.6\end{array}$ \\
\hline $\begin{array}{l}\text { Total ....... } \\
\text { Total eggs } \\
\text { laid } \ldots . . . . \\
\text { Av. weight of } \\
\text { eggs } \ldots . . .\end{array}$ & $\begin{array}{r}142,095 \\
2,424 \\
58.6\end{array}$ & $\begin{array}{r}139,350 \\
2,374 \\
58.7\end{array}$ & $\begin{array}{r}129,605 \\
2,178 \\
59.5\end{array}$ & $\begin{array}{r}68,604 \\
1,211 \\
56.6\end{array} \mid$ & $\begin{array}{r}64,569 \\
1,126 \\
57.3\end{array}$ & $\begin{array}{r}69,289 \\
1,205 \\
57.5\end{array}$ & 613,512 & \\
\hline
\end{tabular}

The table also shows that the scanty feeding of pens 6 , 7 and 8 materially reduced the size of the eggs. Pens 3,4 and 5 laid 6,767 eggs, weighing 4II,050 grams or an average of 58.92 grams each, while pens 6,7 and 8 laid 3,542 eggs weighing 202,462 grams or an average of $57.4 \mathrm{I}$ grams. This makes an average difference of I.jI grams per egg throughout the year. 


\section{Increase in Weight of Egg Due to Age of Fowls.}

During the first year of the test the eggs from pens 3,4 and 5 had an average weight of 57.5 grams. During the second year the eggs had an average weight of 58.92 grams or an increase, due apparently to the increased age of the fowls, of I.4 grams per egg. This indicates the importance of breeding only from mature stock. The results for the two years from pens 6,7 and 8 are not strictly comparable as these pens were fed liberally a portion of the time during the first year of the test.

During the first year of the test, the eggs from pens 3 and 4 , pullets, averaged respectively, 56.8 and 56.6 grams. The eggs from the yearling hens, pen 4 . however, averaged 59.2 grams or, in other words, they averaged about $21 / 2$ grams apiece heavier than the eggs laid by pullets.

Average Weight of Eggs, in Grams, for Each Month of the Year.

\begin{tabular}{|c|c|c|c|c|c|c|}
\hline & Pen 3 & Pen 4 & Pen 5 & Pen 6 & Pen 7 & Pen 8 \\
\hline August, $1912 \ldots \ldots \ldots$. & 57.87 & 57.40 & 58.89 & 55.64 & 55.60 & 57.08 \\
\hline September $\ldots \ldots \ldots \ldots \ldots$ & 59.46 & 58.76 & 60.22 & 58.30 & 56.19 & 56.69 \\
\hline October $\quad \ldots \ldots \ldots \ldots \ldots \ldots$ & 60.28 & 58.15 & 61.68 & & 57.00 & 48.00 \\
\hline November $\quad . . \ldots \ldots$. & 61.00 & & & & 51.00 & \\
\hline December & 61.38 & 58.00 & & 68.66 & & 60.42 \\
\hline January, 1913. & 60.15 & 58.42 & 57.18 & 63.54 & 61.87 & 65.28 \\
\hline February $\quad .$. & 60.00 & 57.72 & 57.23 & 62.33 & 62.41 & 60.77 \\
\hline March .. & 60.71 & 61.02 & 61.76 & 58.91 & 58.59 & 59.08 \\
\hline April ... & 59.63 & 59.30 & 62.03 & 55.91 & 56.61 & 56.59 \\
\hline May .... & 57.73 & 58.09 & 60.63 & 54.56 & 54.93 & 54.50 \\
\hline June $\ldots .$. & 57.40 & 57.84 & 60.22 & 54.73 & 56.66 & 55.93 \\
\hline July $\ldots$. & 57.48 & 58.23 & 59.10 & 55.20 & 56.76 & 56.97 \\
\hline
\end{tabular}

\section{ADDITIONAL EXPERIMENTS CONDUCTED IN 1913.}

To continue the study of liberal versus scanty feeding upon the hatchability of the eggs and the vigor of the chicks three hatches were carried out in the spring of I9I3 by Mr. Stuart A. Cody, Assistant Poultryman. The details of these tests follow:

\section{Incubation Tests.}

On April Io, I9I 3, 366 eggs laid by pens 3,4 and 5 and 353 eggs laid by pens 6,7 and 8 were placed in Cyphers incubators. The following table shows the details of the hatch: 
TEST 1-April 10, 191.3.

\begin{tabular}{|c|c|c|c|c|c|c|}
\hline & 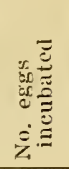 & 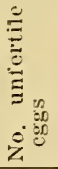 & 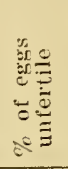 & 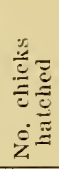 & 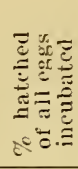 & 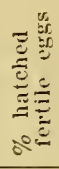 \\
\hline 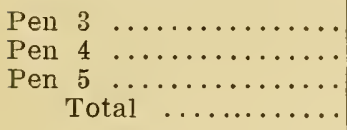 & $\begin{array}{l}107 \\
109 \\
144 \\
360\end{array}$ & $\begin{array}{l}32 \\
10 \\
37 \\
79\end{array}$ & $\begin{array}{r}29.9 \\
9.1 \\
25.7 \\
21.9\end{array}$ & $\begin{array}{r}66 \\
81 \\
88 \\
235\end{array}$ & $\begin{array}{l}61.7 \\
74.3 \\
61.1 \\
65.3\end{array}$ & $\begin{array}{l}88.0 \\
81.8 \\
82.2 \\
83.6\end{array}$ \\
\hline 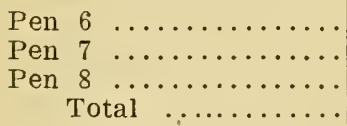 & $\begin{array}{l}106 \\
111 \\
136 \\
353\end{array}$ & $\begin{array}{l}18 \\
54 \\
14 \\
86\end{array}$ & $\begin{array}{l}16.9 \\
48.6 \\
10.1 \\
24.3\end{array}$ & $\begin{array}{r}78 \\
45 \\
105 \\
228\end{array}$ & $\begin{array}{l}73.6 \\
40.5 \\
77.2 \\
64.5\end{array}$ & $\begin{array}{l}88.6 \\
78.9 \\
86.0 \\
85.4\end{array}$ \\
\hline
\end{tabular}

The above table shows that there was practically no difference in the average fertility or hatchability of the eggs from the fowls fed heavily or scantily. There is considerable variation, however, in the results from the different pens, due, probably in large measure, to variations in the vigor of the males.

The chicks were weighed when removed from the incubators. The chicks hatched from eggs laid by fowls fed liberally weighed 8.80 lbs. per hundred chicks, while chicks from the fowls fed scantily weighed at the rate of $8.40 \mathrm{lbs}$. per hundred.

The chicks were toe-marked and placed with about 700 other chicks in an Arenburg brooder, and a record was kept of their mortality until June 26th. Up to that time II.9\% of the chicks from the fowls fed heavily, and $10.9 \%$ of the chicks from the fowls fed scantily, had died.

Eggs from the liberally and scantily fed fowls were placed in Cyphers incubators June 9, I9I3. The following table shows the details of the hatch:

TEST 2-June 9, 1913.

\begin{tabular}{|c|c|c|c|c|c|c|}
\hline Lot & 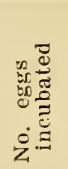 & 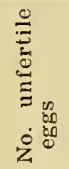 & 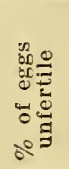 & 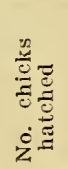 & 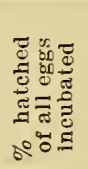 & 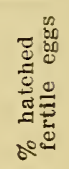 \\
\hline Lot I-Fed liberally... & 512 & 97 & 18.9 & 238 & 46.4 & 57.3 \\
\hline Lot II-Fed scantily... & 251 & 29 & 11.5 & 79 & 31.4 & 35.6 \\
\hline
\end{tabular}


The table shows that the eggs from the fowls fed scantily did not hatch nearly so well as the eggs from the other lot of fowls. This result may have been dite, hovever, to the fact that through oversight, the ventilators in the machine containing the eggs from the fowls fed scantily, remained closed throughout the hatch, while the ventilators in the other machine were kept open.

The chicks from the liberally fed fowls weighed, when removed from the incubator, 8.76 lbs. per hundred chicks, and $7.9 \mathrm{I}$ lbs. per hundred in the case of the other lot.

The chicks were marked and placed in a hot water pipebrooder house and a record was kept of all deaths due to weakness or disease until the chicks were eight weeks old. During that time $36.5 \%$ of the chicks died from lot I or from eggs laid by fowls fed liberally, and $27.8 \%$ of the other chicks. The mortality in both cases was high.

TEST 3-JUTy 11, 1913.

\begin{tabular}{|c|c|c|c|c|c|c|}
\hline Lot & 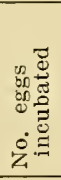 & 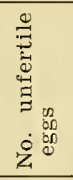 & 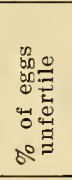 & 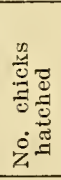 & 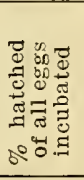 & 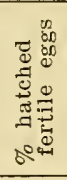 \\
\hline Lot I-Fed liberally.. & 297 & 110 & 37.0 & 117 & 39.3 & 62.5 \\
\hline Lot II-Fed scantily.. & 98 & 29 & 29.6 & 28 & 28.5 & 40.6 \\
\hline
\end{tabular}

The table shows that the eggs from lot II did not hatch so well as those from lot I. The chicks were weighed when taken from the incubator. Those from lot I weighed 8.09 lbs. per hundred chicks, and those from lot II 8.12 lbs. per hundred.

A record was kept of the mortality of these chicks until September 3oth. At that time $29.9 \%$ of the chicks from lot $I$ and $64.3 \%$ of the chicks from lot II had died from various. causes.

\section{Conclusions Concerning Hatchability of Eggs and Weight of Chicks.}

The following table brings together the results obtained. during the two years: 


\begin{tabular}{|c|c|c|c|c|c|c|c|}
\hline \multirow{2}{*}{\multicolumn{2}{|c|}{ Hatch }} & \multicolumn{2}{|c|}{$\%$ Fertile Eggs } & \multicolumn{2}{|c|}{$\begin{array}{l}\text { \% Hatched of all } \\
\text { Eggs Incubated }\end{array}$} & \multicolumn{2}{|c|}{$\begin{array}{c}\% \text { Hatched of } \\
\text { Fertile Eggs }\end{array}$} \\
\hline & & 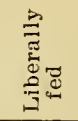 & 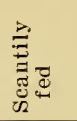 & 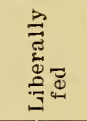 & 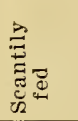 & 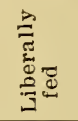 & 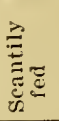 \\
\hline No. 1-1912 & . & 65.9 & 42.6 & 53.9 & 32.9 & 81.9 & 77.5 \\
\hline No. $2-1912$ & $\ldots$ & 94.0 & 86.0 & 82.5 & 79.5 & 87.7 & 92.5 \\
\hline No. $3-1912$ & & 92.6 & 86.6 & 78.7 & 77.4 & 85.1 & 89.3 \\
\hline No. $4-1912$ & & 87.8 & 87.6 & 77.8 & 77.3 & 87.9 & 88.2 \\
\hline No. $5-1912$ & & 80.2 & 88.2 & 67.4 & 80.0 & 84.1 & 90.7 \\
\hline No. $1-1913$ & & 83.1 & 75.7 & 65.3 & 64.5 & 83.6 & 85.4 \\
\hline No. $2-1913$ & & 81.1 & 88.5 & 46.4 & 31.4 & 57.3 & 35.6 \\
\hline No. $3-1913$ & & 63.0 & 70.4 & 39.3 & 28.5 & 62.5 & 40.6 \\
\hline
\end{tabular}

With a single exception, (hatch 5-I912), the eggs from the fowls fed liberally produced a larger number of chicks from a given number of eggs incubated than was the case with the eggs from fowls fed scantily and the exception itself is more apparent than real, for in May I9I2, when the hatch in question was made, the scantily fed fowls were laying practically as well as those fed liberally.

The following table indicates the relative mortality:

\begin{tabular}{|c|c|c|c|c|c|}
\hline & \multirow[b]{2}{*}{ Hatch } & \multicolumn{2}{|c|}{$\begin{array}{l}\text { Weight of Chicks } \\
\text { per hundred }\end{array}$} & \multicolumn{2}{|c|}{$\%$ Mortality } \\
\hline & & 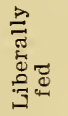 & 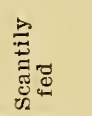 & 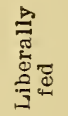 & 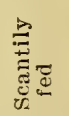 \\
\hline No. $2-1912$ & . . & & & 7.3 & 0 \\
\hline No. $3-1912$ & $\ldots \ldots \ldots \ldots$ & 8.77 & 8.38 & 3.8 & 1.6 \\
\hline No. $4-1912$ & & 8.58 & 8.73 & 4.1 & 0 \\
\hline No. $5-1912$ & & 8.92 & 8.80 & 1.5 & 2.9 \\
\hline No. $1-1913$ & & 8.80 & 8.40 & 11.9 & 10.9 \\
\hline No. $2-1913$ & $\ldots \ldots$ & 8.76 & 7.91 & 36.5 & 27.8 \\
\hline No. $3-1913$ & $\ldots \ldots \ldots$ & 8.09 & 8.12 & 29.9 & 64.3 \\
\hline
\end{tabular}

If the hatch of I9I2 be disregarded, as pens 6 and 7 were being fed in a normal manner at the time that hatch was made, it is evident from the table that the chicks hatched from eggs laid by the fowls fed liberally averaged somewhat heavier than those hatched from the other eggs.

Mortality of Chicks. In some cases there was a slightly greater mortality among chicks from the liberally fed fowls, but too much stress should not be placed on these figures, as so many uncontrollable factors may have intervened as to have vitiated the results 


\section{SEASONAL VARIATION IN THE COMPOSITION OF HEN EGGS.}

Inasmuch as there seems to be a seasonal variation in the weight of eggs it is of interest to observe whether there is any seasonal variation in their composition or in the relative proportions of the different parts. The following tables are the results of analyses performed by Mr. K. H. Knudsen, formerly Assistant Chemist of the Experiment Station. The eggs analyzed were taken from pen 3 previously mentioned. The methods used in these analyses are described on page IOo and following, of this bulletin.

Composition of Yolks.

\begin{tabular}{|c|c|c|c|c|c|c|}
\hline Date & 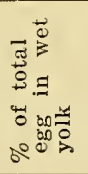 & 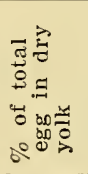 & 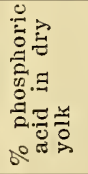 & 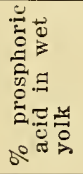 & 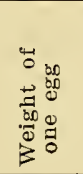 & 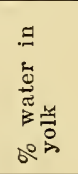 \\
\hline Oct. $\quad 8,1911 \ldots$ & & 13.53 & 2.62 & 1.36 & & 48.14 \\
\hline Oct. $14,1911 \ldots$ & & 12.81 & 2.61 & 1.35 & & 48.15 \\
\hline Oct. $16,1911 \ldots$ & & 13.08 & 2.58 & 1.30 & & 49.44 \\
\hline Oct. $21,1911 \ldots$ & & 15.99 & 2.62 & 1.37 & & 47.90 \\
\hline April $\quad 9,1912 \ldots$ & 29.65 & 15.07 & 2.68 & 1.39 & 59.75 & 47.98 \\
\hline April $11,1912 \ldots$ & 31.65 & 16.25 & 2.62 & 1.35 & 58.48 & 48.60 \\
\hline April $24,1912 \ldots$ & 29.80 & 15.38 & 2.66 & 1.37 & 54.77 & 48.38 \\
\hline Average & 30.35 & 14.59 & 2.63 & 1.35 & 57.66 & 48.39 \\
\hline
\end{tabular}

The average per cent of the total egg that is dry yolk, for the four analyses performed in October I9II, is I3.85, while the average for the three analyses performed in April is 15.56 .

Although these anaylses are too few in number to allow any definite conclusions to be drawn, still, the figures indicate that the yolks of eggs are relatively heavier in respect to the total egg, in the spring than in the fall. This point should be studied further.

There seems to be no other striking difference between the fall and spring analyses, except that the average per cent of phosphoric acid in the dry yolk was 2.607 for October and 2.653 for April. This matter also should be studied further. 
Composition of Whites.

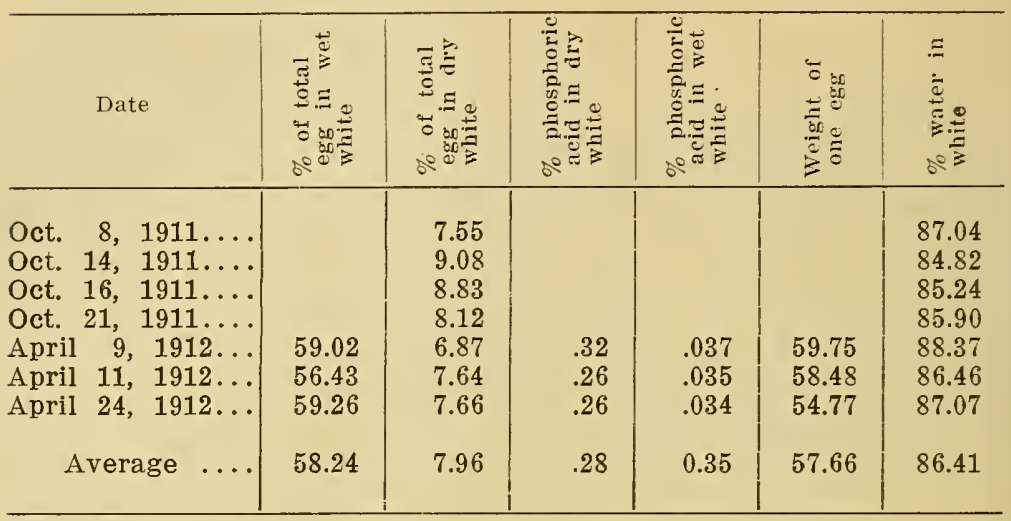

In this table the most striking feature is the high relative proportion of the weight of the dry white to the weight of the total egg, in the fall and in the spring. The average per cent for October was 8.395, while for April it was slightly more than one per cent less or 7.390. This is in accord with the results shown in the preceding table.

Composition of shell.

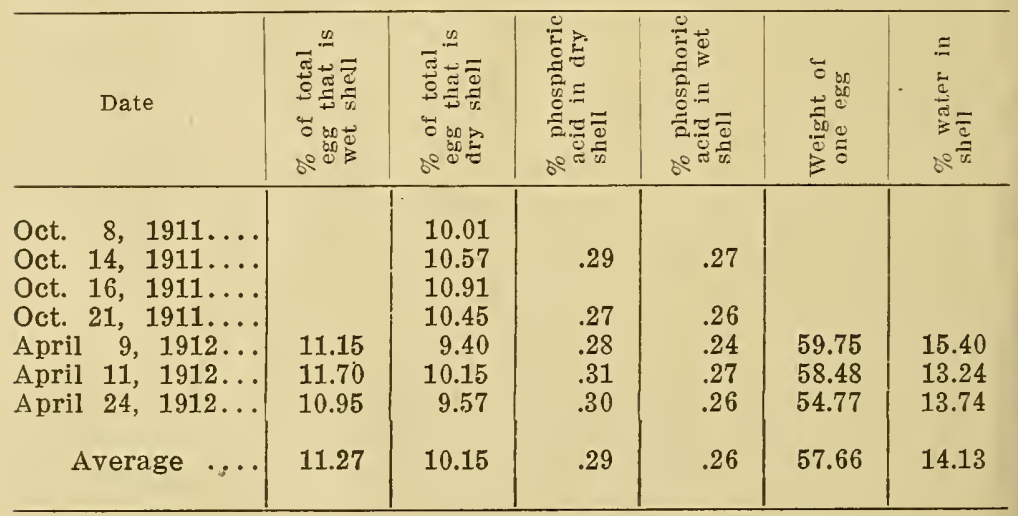

In this table the only figures available for October and April are in reference to the per cent of the total egg that is dry shell. The average for October is slightly greater than for April. 


\section{Conclusions.}

Although the analyses are too few to justify drawing definite conclusions, yet the results indicate that during spring when hens are laying well, and when the eggs are heavier than at any other time of the year, then the dry matter of the yolk constitutes a greater percentage of the total weight of the egg than in the fall when the fowls are laying less liberally. This may be an additional reason why early hatched chickens are more vigorous than those hatched later, for it is reasonable to suppose that the larger the yolk the more perfectly nourished will be the embryo.

\section{THE INFLUENCE OF CERTAIN RATIONS ON THE SIZE AND COMPOSITION OF HEN EGGS.}

The question often arises whether the amount of phosphorus in a ration for laying hens affects either the number of eggs laid, their size, or their composition.

If a lack of sufficient phosphorus causes a diminution in the phosphorus content of the eggs produced, this possibly may be one reason why late hatched chicks are less thrifty than those hatched earlier in the season. It is conceivable that a fowl during the normal resting period while moulting and before beginning to lay, stores up a supply of phosphorus in the body which is drawn upon to supplement the amount assimilated from the ration, thus providing the early laid eggs with a liberal supply of the necessary phosphorized materials present in the yolk substances, and that, later in the season. the available stored-up body phosphorus having been used up, the eggs may be less abundantly supplied with these essential compounds, with the effect that the resulting chickens are less perfectly nourished and consequently are weaker. In the absence of a sufficient stipply of phosphorus it is conceivable, also, that even though the composition of the phosphorized yolk substances remain unchanged, the relative amount of yolk may be diminished thus weakening the chick. To study this matter a feeding experiment was carried out, and many eggs analyzed by Professor H. K. Knudsen, formerly Assistant Chemist of the Station.

\section{Rations Rich and Poor in Phosphorus Fed to Laying Hens.}

This experiment was started February I7, I9I2 and was continued until August Ist, with two lots of Single Comb White Leghorn fowls, each consisting of ten pullets and one cockerel. 
Both lots were fed dry mash, in hoppers, consisting of a mixture of bolted corn meal and gluten flour. The whole grain consisted of rice fed ad libitum in hoppers. In addition to the rice and mash, pen I received granulated bone and mica crystal grit ad libitumn; pen 2, instead of granulated bone received oyster shell.

The following tables show the composition of the feeding stuffs employed and the amounts consumed:

\begin{tabular}{|c|c|c|c|c|c|c|}
\hline \multicolumn{2}{|l|}{ Feeding Stuffs } & \multicolumn{2}{|c|}{ 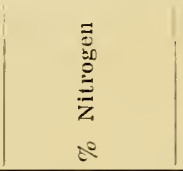 } & $\begin{array}{l}\bar{z} \\
\stackrel{0}{0} \\
\approx 0\end{array}$ & \multicolumn{2}{|r|}{ 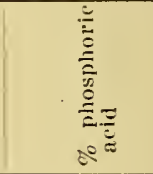 } \\
\hline \multicolumn{2}{|c|}{$\begin{array}{l}\text { Granulated bone } \ldots \ldots \ldots \ldots \ldots \ldots \\
\text { Gluten flour } \ldots \ldots \ldots \ldots \ldots \ldots \ldots \ldots \\
\text { Corn meal } \ldots \ldots \ldots \ldots \ldots \ldots \ldots \\
\text { Rice } \ldots \ldots \ldots \ldots \ldots \ldots \ldots \\
\text { Oyster shell } \ldots \ldots \ldots \ldots \ldots \ldots \ldots\end{array}$} & \multicolumn{2}{|c|}{\begin{tabular}{|r|}
4.13 \\
12.9 \\
1.38 \\
1.23 \\
Only a t
\end{tabular}} & $\begin{array}{r}64.45 \\
.66 \\
.60 \\
.80 \\
\text { of pho }\end{array}$ & \multicolumn{2}{|c|}{\begin{tabular}{|r}
23.83 \\
.41 \\
.20 \\
.34
\end{tabular}} \\
\hline Pen & 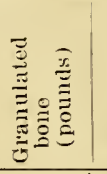 & 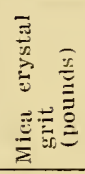 & 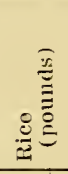 & 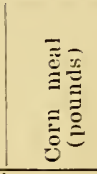 & 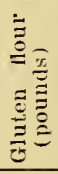 & 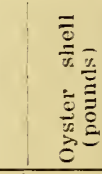 \\
\hline Pen $1 \ldots \ldots \ldots \ldots$. & 49 & 9.25 & 244 & 77 & 18 & \\
\hline Pen $2 \ldots \ldots \ldots \ldots \ldots$ & & 9. & 212 & $80^{\circ}$ & 19 & 19 \\
\hline
\end{tabular}

The following table shows the egg production by months, the weight of the eggs, and the average weight in grams.

\begin{tabular}{|c|c|c|c|c|c|c|}
\hline \multirow[b]{2}{*}{ Nonth } & \multicolumn{3}{|c|}{ PEN 1} & \multicolumn{3}{|c|}{ PEN 2} \\
\hline & 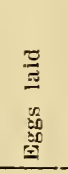 & 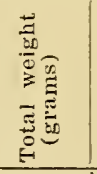 & 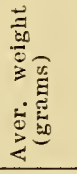 & 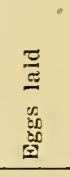 & 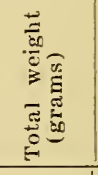 & 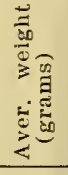 \\
\hline Feb. (17). & 56 & 3,078 & 54.9 & 30 & 1,696 & 56.5 \\
\hline March ..... & 136 & 7,430 & 54.6 & 82 & 4,610 & 56.2 \\
\hline April $\ldots \ldots \ldots \ldots \ldots$ & 162 & 8,518 & 52.6 & 100 & 5,483 & 54.8 \\
\hline 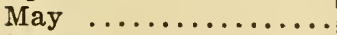 & 174 & 9,280 & 53.3 & 82 & 4,363 & 53.2 \\
\hline June $\ldots \ldots \ldots \ldots \ldots$ & 158 & 8,391 & 53.1 & 69 & 3,704 & 53.6 \\
\hline July $\ldots . . . \ldots \ldots$ & 70 & 3,688 & 52.7 & 23 & 1,219 & 53. \\
\hline Total ...... & 756 & 40,385 & & 386 & 21,075 & \\
\hline Average ......... & & & 53.4 & & & 54.6 \\
\hline
\end{tabular}


The above table shows that pen $\mathrm{I}$, which received granulated bone laid almost twice as many eggs as pen 2 with oyster shell. It must be remembered, however, that the grain part of the ration was selected with particular reference to its low phosphorus content. Also it must be remembered that the granulated bone contained 4.I3\% nitrogen which might have had some effect in stimulating the greater egg production of pen I, but as the gluten flour supplied to both lots of fowls was very rich in nitrogen, it is entirely probable that enough protein was available from this source for both flocks.

The following tables show the results of analyses made of eggs laid by each lot of fowls:

Composition of Yolks.

YOLK OF PEN NO. 1.

\begin{tabular}{|c|c|c|c|c|c|c|c|}
\hline Date & 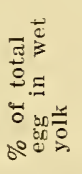 & 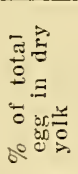 & 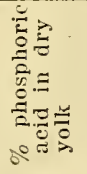 & 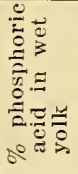 & 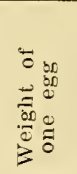 & 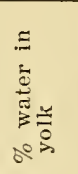 & 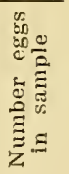 \\
\hline Feb. 26, 1912. & 28.85 & 15.00 & 2.60 & 1.35 & 56.85 & 48.02 & 2 \\
\hline March 1, 1912...... & 30.56 & 16.05 & 2.59 & 1.36 & 53.18 & 47.47 & 6 \\
\hline March 5, 1912. & 31.26 & 15.85 & 2.66 & 1.35 & 54.82 & 49.28 & 12 \\
\hline March 11, 1912. & 29.93 & 15.43 & 2.64 & 1.36 & 53.96 & 48.58 & 5 \\
\hline April $9,1912 \ldots$ & 30.88 & 15.89 & 2.64 & 1.36 & 53.98 & 48.54 & 6 \\
\hline April 11, 1912. & 32.53 & 16.56 & 2.63 & 1.33 & 53.75 & 49.12 & 6 \\
\hline April $20,1912 \ldots$ & 31.52 & 16.25 & 2.67 & 1.36 & 52.66 & 48.84 & 6 \\
\hline April $24,1912 \ldots \ldots$ & 30.78 & 15.64 & 2.66 & 1.35 & 51.83 & 49.17 & 6 \\
\hline Average & 30.79 & 15.83 & 2.64 & 1.35 & 53.88 & 48.63 & \\
\hline
\end{tabular}

YOLK OF PEN NO. 2.

\begin{tabular}{|c|c|c|c|c|c|c|c|}
\hline Feb. 26, 1912. & 29.12 & 15.46 & 2.66 & 1.41 & 60.77 & 46.92 & 2 \\
\hline March 1, 1912.. & 31.23 & 15.78 & 2.64 & 1.33 & 58.02 & 49.48 & 6 \\
\hline March $5,1912, \ldots$. & 29.40 & 15.01 & 2.64 & 1.35 & 57.48 & 48.96 & 9 \\
\hline March 11, 1912.... & 29.24 & 14.82 & 2.59 & 1.31 & 53.42 & 49.34 & 5 \\
\hline April 9, 1912.. & 30.78 & 15.63 & 2.68 & 1.36 & 54.80 & 49.21 & 6 \\
\hline April 11, 1912.. & 32.00 & 16.35 & 2.57 & 1.31 & 54.00 & 48.88 & 6 \\
\hline April 20, 1912. & 30.29 & 15.27 & 2.63 & 1.32 & 54.25 & 49.71 & 6 \\
\hline April 24, 1912. & 28.25 & 14.48 & 2.67 & 1.36 & 53.57 & 48.88 & 6 \\
\hline Average .. & 30.04 & 15.35 & 2.63 & 1.34 & 55.79 & 48.92 & 6 \\
\hline
\end{tabular}


Composition of Whites.

WHITE OF PEN NO. 1.

\begin{tabular}{|c|c|c|c|c|c|c|c|}
\hline Date & 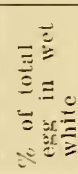 & 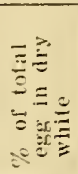 & 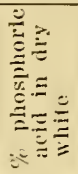 & 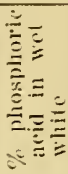 & 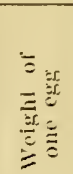 & 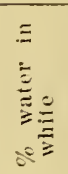 & 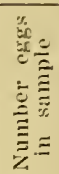 \\
\hline Feb. 26, 1912.. & 57.88 & 8.23 & .30 & .043 & 56.85 & 85.77 & 2 \\
\hline March $1,1912 \ldots$ & 52.77 & 7.33 & .27 & .037 & 53.18 & 86.11 & 6 \\
\hline March $5,1912 \ldots$. & 55.58 & 6.78 & .28 & .034 & 54.82 & 87.80 & 12 \\
\hline March $11,1912 \ldots$. & 58.02 & 7.00 & .28 & .034 & 53.96 & 87.93 & 5 \\
\hline April $9,1912 \ldots .$. & 57.46 & 7.07 & & & 53.98 & 87.98 & 6 \\
\hline April $11,1912 \ldots \ldots$ & 55.53 & 7.08 & .31 & .040 & 53.75 & 87.25 & 6 \\
\hline April 20,1912 & 56.25 & 6.90 & .24 & .029 & 52.66 & 87.73 & 6 \\
\hline April $24,1912 \ldots$ & 56.88 & 7.08 & .26 & .032 & 51.83 & 87.55 & 6 \\
\hline Average..... & 56.30 & 7.18 & .28 & .036 & 53.88 & 87.27 & \\
\hline
\end{tabular}

WHITE OF PEN NO. 2.

\begin{tabular}{|c|c|c|c|c|c|c|c|}
\hline Feb. 26, 1912. & 60.64 & 8.33 & .27 & .036 & 60.77 & 86.50 & 2 \\
\hline March $1,1912 \ldots \ldots$ & 55.92 & 7.08 & .27 & .034 & 58.02 & 87.34 & 6 \\
\hline March $5,1912 \ldots \ldots$ & 58.80 & 7.54 & .29 & .037 & 57.48 & 87.18 & 9 \\
\hline March 11, 1912..... & 58.33 & 7.15 & .29 & .036 & 53.42 & 87.75 & 5 \\
\hline April $\quad 9, \quad 1912 \ldots \ldots$ & 57.39 & 7.14 & .31 & .039 & 54.80 & 87.56 & 6 \\
\hline April $11,1912 \ldots \ldots$ & 55.71 & 6.99 & .29 & .036 & 54.00 & 87.45 & 6 \\
\hline April $20,1912 \ldots$ & 58.56 & 7.28 & .29 & .036 & 54.25 & 87.57 & 6 \\
\hline April $24,1912 \ldots \ldots$ & 60.45 & 7.82 & .24 & .031 & 53.57 & 87.07 & 6 \\
\hline Average .. & 58.23 & 7.42 & .28 & .036 & 55.79 & 87.30 & \\
\hline
\end{tabular}

Composition of Shells.

SHELLS OF PEN NO. 1.

\begin{tabular}{|c|c|c|c|c|c|c|c|}
\hline Date & 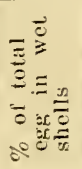 & 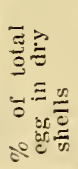 & 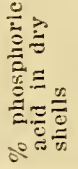 & 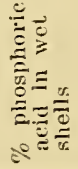 & 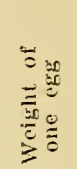 & 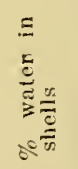 & 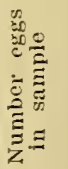 \\
\hline Feb. $26,1912 \ldots \ldots$. & 11.26 & 10.10 & .29 & .26 & 56.85 & & 2 \\
\hline March $1,1912 \ldots \ldots$ & 10.69 & 9.97 & .32 & .30 & 53.18 & & 6 \\
\hline March 5, 1912.... & 11.85 & 10.41 & .30 & .26 & 54.82 & 14.43 & 12 \\
\hline March 11, 1912..... & 12.04 & 9.90 & .31 & .25 & 53.96 & 17.82 & 5 \\
\hline April $9,1912 \ldots \ldots$ & 11.36 & 9.79 & .32 & .28 & 53.98 & 13.90 & 6 \\
\hline April 11, 1912..... & 11.78 & 10.21 & .29 & .25 & 53.75 & 13.33 & 6 \\
\hline April $20,1912 \ldots$ & 11.38 & 9.76 & .29 & .24 & 52.66 & 16.98 & 6 \\
\hline April 24, $1912 \ldots \ldots$. & 11.65 & 10.17 & .29 & .25 & 51.83 & 12.76 & 6 \\
\hline Average .. & 11.50 & 10.04 & .30 & .26 & 53.88 & 14.87 & \\
\hline
\end{tabular}


SHELLS OF PEN NO. 2.

\begin{tabular}{|c|c|c|c|c|c|c|c|}
\hline Feb. 26, 1912. & 9.54 & 8.47 & .27 & .24 & 60.77 & & 2 \\
\hline March $1,1912 \ldots$. & 11.52 & 9.76 & .28 & .24 & 58.02 & 15.23 & 6 \\
\hline $5,1912 \ldots \ldots$ & 11.02 & 9.55 & .27 & .23 & 57.48 & 13.32 & 9 \\
\hline March $11,1912 \ldots$. & 11.75 & 9.93 & .31 & .26 & 53.42 & 15.55 & 5 \\
\hline April $9, \quad 1912 \ldots \ldots$ & 11.36 & 9.44 & .29 & .24 & 54.80 & 16.91 & 6 \\
\hline April $11,1912 \ldots \ldots$ & 11.40 & 9.81 & .28 & .24 & 54.00 & 14.51 & 6 \\
\hline April $20,1912 \ldots \ldots$ & 10.83 & 9.40 & .28 & .24 & 54.25 & 13.17 & 6 \\
\hline April $24,1912 \ldots \ldots$ & 11.26 & 9.85 & .29 & .25 & 53.57 & 12.30 & 6 \\
\hline Average & 11.08 & 9.53 & .28 & .24 & 55.79 & 14.43 & \\
\hline
\end{tabular}

\section{The Yolks.}

Taking up first the composition of the yolks of the eggs from pens I and 2 , the table shows that both the wet and dry yolks of the eggs laid by pen I constituted a larger proportion of the total egg substance than was the case in pen 2 . The average for pen I gives 30.79 per cent of the total weight of the eggs that were wet yolks, and 30.04 for pen 2. This is a variation of 2.4 per cent, and indicates that when there is a lack of sufficient phosphorus in the ration, the size of the yolk will be diminished. Also, there seems to be slightly more phosphorus in the dry matter itself, where the fowls received an abundant supply of phosphorus in the ration.

The eggs from pen 2 that were analyzed, averaged slightly heavier than those from pen $\mathrm{I}$. This is in harmony with the table on page 92 .

\section{The Whites.}

Inasmuch as the yolks from pen I were relatively heavier than the yolks from pen 2, one would naturally expect the whites from pen I to be relatively lighter thain those from pen 2. The tables show this to be the case, as the wet whites average 56.30 per cent of the total weight of the eggs in the case of pen. $I$ and 58.23 per cent in the case of pen 2 . As the analyses of yolk, white and shells were all direct determinations this gives a check upon the accuracy of the analytical results.

The percentage of phosphorus in the whites is identical in both instances, but the percentage of moisture in the whites from pen 2 is slightly greater.

\section{The Shells.}

Somewhat contrary to what might be expected the shells of the eggs laid by the forls fed granulated bone, were some- 
what heavier in proportion to the total weight of the eggs than was the case with the eggs laid by the fowls fed oyster shell. This variation was practically 5 per cent of the dry weight of the shell.

There was .30 per cent phosphoric acid in the dry shells of pen I and .28 per cent in the shells of pen 2 . This is a difference of two parts in thirty or 6.66 per cent. This would indicate that some of the tri-calcium phosphate of the granulated bone was used for shell material. Whether this increased amount of phosphorus laid down in the shell can be assimilated by the developing embryo remains for future experiments to determine. It is known however, that a considerable quantity of calcium carbonate is removed from the shell by the embryo during its development and enters directly into the tissues and structure of the chick.

\section{Does the Ordinary Grain Ration Contain Sufficient Phosphorous?}

In connection with this investigation it is of interest to determine whether a ration for egg production consisting of grain only, contains sufficient phosphorus for maximum egg production. For our purposes let us select wheat, since this grain contains somewhat more phosphorus than corn. In round numbers a fowl will consume about 70 pounds of grain per year. According to the generally accepted tables, wheat contains $.85 *$ per cent phosphoric acid. Consequently seventy pounds of wheat would contain .595 of a pound of phosphoric acid.

The table on page 77 shows that pen 3 laid during the year 158,9 ro grams of eggs. As there were 20 layers in that pen each hen laid an average of 7.945 .5 grams of eggs.

The average of all analyses of eggs laid by pen I showed that they contained .47 per cent of phosphoric acid. Making the necessary calculation it is seen that a fowl laying as well as the fowls in pen 3 would require in the course of a year 37.34 grams phosphoric acid for use solely in egg building. This is equivalent to .082 of a pound or slightly more than one-seventh of that contained in the 70 pounds of wheat.

As far as the writer is aware there are no tables showing the average digestibility of phosphoric acid in the various feeding stuffs. At least no experiments along this line have been performed with poultry, but these figures would indicate that there is enough phosphoric acid in the ordinary grains

*Lanes' and Gilbert's Tables. 
for all the requirements of fowls. Other experiments tend to show however, that the phosphorus in a ration consisting entirely of grain, has a very low digestibility and that fowls have great difficulty in getting enough phosphorus for their needs from this source.

In bulletins No. I49 and I7I of the New York Agricul. tural Experiment Station, are recorded the results of experiments by $\mathrm{W}$. P. Wheeler in feeding rations wholly of vegetable origin as compared with rations partly of animal origin. The latter of course, containing much larger amounts of phosphorus than the rations wholly of vegetable origin. The following quotations are from the publications referred to.

"The rations in which from 40 to 50 per cent of the protein was supplied by animal food gave in every trial, (with chicks, pullets, cockerels and ducklings) more economical results that the contrasted rations in which most of the protein came from vegetable sources"

"Although it was found possible, when using a large number of foods in contrasted rations of these kinds, to have the ordinary groups of organic compounds in approximately equal proportions, there was always a much larger amount of mineral matter in the one ration, owing to the bone of the animal meal. Consequently there was sometimes nearly three times as much phosphorus in the one ration as in the other. Calculating all the phosphorus as phosphoric acid there was in the animal meal ration fed to chicks and hens generally about 3.9 per cent of phosphoric acid, while in the ration of vegetable origin there was about $\mathrm{I} .4$ per cent. In the contrasted rations for ducklings there were 4.0 per cent, and I.9 per cent of phosphoric acid respectively."

"By using bone ash in another series of experiments the amount of phosphorus was made to equal and sometimes to slightly exceed that in the animal food ration, although all the organic matter was still derived from vegetable food. There was in the animal food ration fed to chicks, phosphorus equivalent to about 3.9 per cent of phosphoric acid and in the contrasted rations about 4 per cent. The animal food ration for ducklings contained about 3.6 per cent of phosphoric acid, and the vegetable food ration about 4.0 per cent. Both rations for laying hens contained about 3.6 per cent of phosphoric acid. Practically the same relative amounts of protein, fats and carbohydrates existed in the contrasted rations. The vegetable food ration, thus supplemented by the mineral matter of bone ash, when fed to chicks proved fully equal to the ration containing animal meal so far as rapidity of growth was concerned. In economy it was even somewhat superior, 
for considerably less food was required for equal results. For laying hens the rations were equal in efficiency for several months, but the ration containing animal food proved somewhat more enduring in its effects. With ducklings the ashsupplemented ration of vegetable food proved decidedly inferior to the corresponding ration containing animal food."

"From these results it appears that rations containing a necessary amount of protein and having the relation of the ordinary constituents considered satisfactory, may be inferior because of a lack of mineral matter, probably phosphates."

\section{Further Experiments Concerning the Phosphorus Content of Poultry Rations.}

This test was begun January 3rd., I9I3, with two lots of Single Comb White Leghorn pullets, each lot containing fifteen pullets and one cockerel, and was continued for I35 days. The pullets were from a late hatch and were just beginning to lay, when the test began.

The following table shows the average weight of the fowls at the beginning of the test and at various times during the test:

Weight of Fowls (Pounds).

\begin{tabular}{|c|c|c|}
\hline Jlonth & Pen 1 & Pen 2 \\
\hline 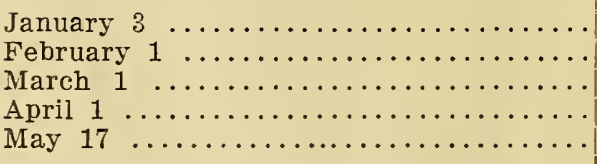 & $\begin{array}{l}4.00 \\
3.92 \\
3.88 \\
3.66 \\
3.36\end{array}$ & $\begin{array}{l}4.17 \\
4.09 \\
4.12 \\
3.75 \\
3.39\end{array}$ \\
\hline
\end{tabular}

Both pens decreased in weight during the test. One hen was removed from pen I March 3 Ist., and another hen February 26th, both being out of condition.

Amount and Kind of Feed Consumed (Pound's).

\begin{tabular}{|c|c|c|}
\hline Feed & Pen 1 & Pen 2 \\
\hline 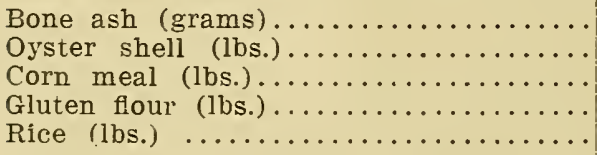 & $\begin{array}{l}5,308 \\
138 \\
27.6 \\
171\end{array}$ & $\begin{array}{r}9.5 \\
135 \\
27 \\
202\end{array}$ \\
\hline
\end{tabular}


The following tables show the number of eggs laid and their average weight in grams:

Eggs Laid.

\begin{tabular}{|c|c|c|}
\hline Month & Pen 1 & Pen 2 \\
\hline 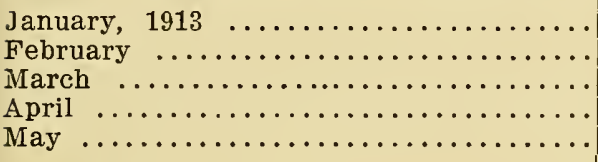 & $\begin{array}{r}49 \\
31 \\
68 \\
148 \\
72\end{array}$ & $\begin{array}{r}23 \\
14 \\
102 \\
137 \\
59\end{array}$ \\
\hline Total & 368 & 335 \\
\hline
\end{tabular}

The above table shows that, in spite of the fact that two hens were removed from pen I, yet the egg production was greater than in the case of pen 2.

Average Weight of Eggs (Grams).

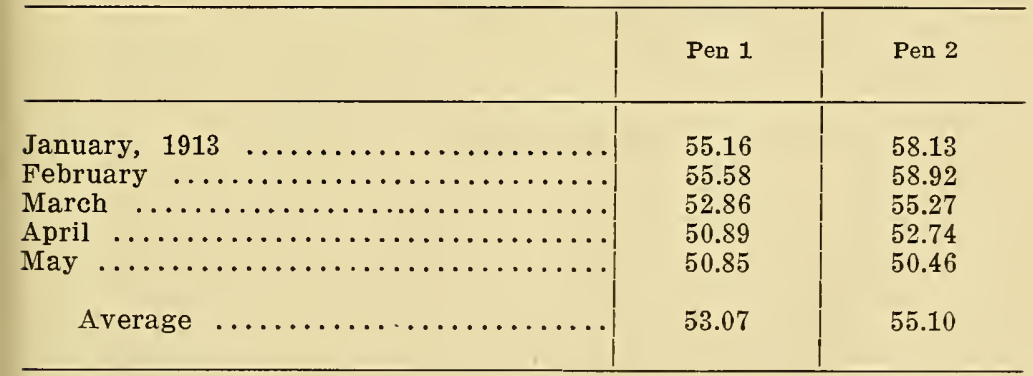

The table shows that the eggs laid by pen 2 were slightly larger than those laid by pen $\mathrm{I}$.

The most striking thing in connection with this table is that there is a gradual decrease in the weight of the eggs. The eggs laid by pullets fed a normal ration, should gradually increase in size as the pullets get older, but in this case there has been a marked decrease showing that the size or weight of the egg depends upon the ration that the fowls receive.

In both instances what must be considered an abnormal ration was fed, and the results indicate that if a fowl is not properly nourished the size of the egg is decreased.

The fowls receiving the bone ash laid better than those fed oyster shells, but it is difficult to understand why the eggs laid by lot 2 should be heavier than those laid by the other lot of fowls, although this is in harmony with the previous year's results. 
The results of these tests indicate that when laying hens are fed a ration too poor in phosphorus the relative size of the yolks of the eggs is reduced; the yolks and shells contain a slightly less percentage of phosphorus; and the total number of eggs laid is materially diminished.

During the course of a year, and under normal conditions there is phosphorus equivalent to about 37 grams of phosphoric acid present in the eggs laid by a hen. The ordinary grain ration fed to laying hens contains several times as much phosphorus as is found in the eggs produced.

This subject needs further study particularly with reference to the influence of small yolks and low phosphorus content of yolks and shells, upon the vigor of chicks hatched from such eggs.

\section{METHODS USED IN ANALYZING EGGS.}

\section{Phosphoric Acid Content in Eggs.}

The chemical composition of eggs is well known, yet the methods of analysis have been but meagerly discussed. As a method had to be adopted for use during the entire investigation in order to obtain comparable results and as each investigator seems to have had a method of his own, it was thought advisable to make some preliminary tests. The main difficulty consists in the elimination of the organic matter without causing a loss of the mineral constituents and this can be accomplished in a wet or dry way.

The wet methods depend on the oxidation of the organic matter by strong acids either alone or with some salt. Digestion with the following acids and salts were taken up: (I) Sulphuric acid and ammonium nitrate. (2) Nitric acid either alone or together with hydrochloric acid or bromine. In each case the digestions required a long time and gave unsatisfactory results. Sulphuric acid and ammonium nitrate will destroy the organic matter but the large amount of sulphates prevents the complete precipitation of the phosphoric acid. The sample went readily into solution with nitric acid, but on dilution and evaporation substances separated out which contained traces of phosphoric acid. 
The well known method of Carius was then resorted todigestion with nitric acid under pressure. The result obtained at 200 degrees C. to 220 degrees C. for four hours were entirely satisfactory, but it was thought best to try to find a less dangerous method. Burning the sample in oxygen in a bomb gave very encouraging results, but it was soon found it would require a bomb especially constructed and this method was abandoned.

The dry methods depend on the oxidation of the organic matter by salts rich in oxygen. This is brought about by mixing thoroughly the salt and sample and gently applying heat. After trying the chlorates, nitrates and peroxides of the alkali metals and alkaline earth metals, it was found that barium nitrate gave the best results. Three grams of the sample were weighed out and ground with six grams of barium nitrate. The mixture was then compressed in a short steel cylinder, the oil and readily volatile matter being absorbed by the barium nitrate. The sample was then carefully removed to a platinum crucible of about 60 cc capacity and placed over a Bunsen burner. Almost instantly combustion took place without smoke or odor. In the course of one minute the combustion was complete, leaving a white ash. The ash was then fused with sodium potassium carbonate in the same crucible. After the fusion was completed it was extracted with hot water and the barium carbonate filtered off. The solution was then acidified and treated as usual. The barium carbonate was dissolved in nitric acid and then concentrated to allow the bulk of the barium nitrate to crystalize out and be filtered off. The filtrate was always found to contain a small amount of phosphoric acid which was precipitated in the regular way and brought on the same filter as the main portion. It was not considered safe to titrate the phospho-molybdate, as it was noticed that free molybdic acid has a tendency to separate out, especially in cases where the barium nitrate had not been separated.

In the combustion it is very essential not to have a large excess of barium nitrate, also that the mixture be compressed into compact shape. The rest1ts obtained by this method checked very well with those obtained by the Carius method.

\section{Preparing the Sample.}

The shell, yolk and white were first separated. This was easily acomplished by hard boiling,-- the loss of phosphates occasioned by the leaching effect of the water being very small.

The samples were then dried in a partial vacuum at the temperature of boiling alcohol. 


\section{GENERAL CONCLUSIONS.}

The average weight of eggs varies from month to month, reaching the maximum in the early spring when the fowls are heaviest and laying most freely.

Eggs from White Leghorns do not reach their maximum weight until the hens are at least in their third laying season.

Scanty feeding reduces the number and size of eggs.

Liberal feeding increases the number and size of eggs.

Eggs from scantily fed fowls do not hatch as well as eggs laid by fowls fed more liberally.

The weight of eggs is reduced when fowls are fed a ration in which the necessary nutritive constituents are not present in proper amount or in proper proportions. 

